\title{
The impact of general and oral health status on removable dentures and quality of life among the elderly. A literature review
}

\author{
Impactul statusului general şi oral la persoanele în vârstă asupra \\ protezării mobile şi calităţii vieţii. Studiu de literatură
}

\author{
Mădălina Bicheru' ${ }^{1}$, Cristina Teodora Preoteasa ${ }^{2}$, Marina Imre ${ }^{1}$, Elena Preoteasa ${ }^{1}$ \\ ${ }^{1}$ Disciplina Protezare Totală, Facultatea de Medicină Dentară, \\ Universitatea de Medicină şi Farmacie „Carol Davila“, Bucureşti, România \\ ${ }^{2}$ Disciplina Ergonomie şi Metodologia Cercetării Ştiinţifice, Facultatea de Medicină Dentară, \\ Universitatea de Medicină şi Farmacie „Carol Davila“, Bucureşti, România
}

\begin{abstract}
REZUMAT
În contextul demografic actual, caracterizat printr-o creştere numerică evidentă a persoanelor în vârstă la nivel global, dar şi în România, se impun cunoaşterea şi abordarea specifică medicală a acestor persoane şi în cadrul tratamentelor protetice.

Metodă. S-a realizat un review narativ, prin analiza datelor din literatură, publicate după anul 2000, privind asocierea dintre statusul general şi oral al pacienţilor în vârstă şi impactul asupra protezării şi calităţii vieţii. Rezultate şi discuţii. Definirea în populaţia de peste 60 de ani a unor subgrupuri de bătrâni - tineri (60-69 ani), de vârstă mijlocie (70-79 ani) şi longevivi (peste 80 ani) - permite o reprezentare mai precisă a schimbărilor semnificative ale vieţii. Plurimorbiditatea şi plurimedicaţia vârstnicului se pot asocia cu manifestări orale (sindromul de „gură uscată“ sau de „gura arsă“), cu afectări generale frecvente (fragilitate, dizabilitate, deteriorare cognitivă), dar şi cu afectări profunde ale statusului oral. Există corelaţii puternice între statusul general şi cel oral la persoanele în vârstă (exemplu: asocierea dintre boala parodontală şi procese inflamatorii de la nivel sistemic) care se manifestă şi în relaţie cu vârsta şi statusul socio-economic. Edentaţia şi protezările mobile convenţionale sau pe implanturi au consecinţe atât la nivel oral, cât şi asupra sănătăţii generale şi calităţii vieţii.

Concluzii. Având în vedere creşterea vârstei medii de viaţă, a numărului persoanelor în vârstă, frecvenţa crescută a bolilor cronice în rândul vârstnicilor, o perspectivă sistemică este absolut necesară în abordarea tratamentului prin protezare. Modalitatea de protezare, calitatea şi acceptarea tratamentelor de către persoanele în vârstă sunt strâns asociate cu starea orală şi generală, cu statusul socio-economic şi calitatea vieţii.
\end{abstract}

Cuvinte cheie: sănătate orală, sănătate generală, persoane în vârstă, proteze, supraproteze pe implanturi, calitatea vieţii

\begin{abstract}
Given the recent demographic trends toward a marked increase of the elderly populations - as evidenced globally and also in Romania, an awareness regarding the specific needs of this age group is required regarding both the general health and the prosthodontic treatment.

Method. A literature review of studies published after the year 2000 was performed, regarding the association between general and oral health among the elderly, as well as the association with the prosthodontic treatment and quality of life.

Results and discussion. Specific elderly groups were first defined: young elderly (60-69 y.o.), middle-aged elderly (70-79 y.o.), and oldest elderly (over 80 y.o.) in order to provide a more clear picture of the transformations occurring among elderly patients. Multiple morbidities and multiple prescription drugs are often associated to oral health symptoms (e.g., the "dry mouth" or "burning mouth" syndromes), to general conditions such as frailty, disability, cognitive impairment, and also to more severe oral health diagnoses. Among the elderly, there is a strong correlation between the general and oral health, such as the one between periodontal disease and systemic
\end{abstract}


inflammatory processes - which are moderated by age and socio-economic status. Thus, edentulation and removable dentures (conventional or implant-sustained) have an impact not only upon oral but also upon systemic health, as well as the overall quality of life.

Conclusions. Given the recent trends toward an increase of the elderly populations, a systemic perspective is absolutely necessary for approaching a prosthetic treatment. The type and quality of dentures, as well as their acceptance by the elderly patient are closely related to the overall and oral health, the social-economic status, and the quality of life of the elderly patient.

Keywords: oral health, general health, elderly, denture, implant overdenture, quality of life

\section{INTRODUCERE}

La nivel global, populația vârstnică este din ce în ce mai numeroasă. Studiile statistice ale World Health Organization arată că, până în anul 2020, numărul celor cu vârsta de peste 60 de ani va depăşi numărul copiilor cu vârsta sub 5 ani, iar până în anul 2050, proporția lor va creşte de la $12 \%$ la $22 \%$ (1). Ponderea populației cu vârsta de peste 65 de ani este în creştere în toate statele membre ale UE (2). Şi în România, ponderea populației vârstnice a înregistrat o creştere semnificativă în ultimii ani, reflectând aceeaşi tendință înregistrată la nivel global. După cum arată datele Institutului Național de Statistică, evoluția structurii populației pe grupe mari de vârstă reflectă amploarea fenomenului de îmbătrânire demografică a populației. Astfel, dacă în 1970 grupa de vârstă de 65 ani şi peste reprezenta $8,6 \%$ din totalul populaţiei, în 2014 această pondere era de aproape două ori mai mare $(15,1 \%)(3)$. În încercarea de a analiza tendințele viitoare ale îmbătrânirii populației, cele mai recente proiecții privind populația (elaborate de Eurostat, EUROPOP 2015) au acoperit perioada 2015-2080. Astfel, se preconizează că persoanele mai în vârstă vor reprezenta probabil o pondere în creştere din populația totală: persoanele în varstă de 65 de ani sau peste vor reprezenta $29,1 \%$ din populația UE până în 2080, în comparație cu procentul de 19,2\% înregistrat în 2016. Ponderea persoanelor în vârstă de 80 de ani sau peste raportată la populația UE este estimată să crească de peste două ori în perioada 20162080 , de la 5,4\% la 12,7\% (2). Aceste modificări demografice aduc cu ele şi modificări în prevalența unor boli cronice în rândul populației, cum ar fi unele tipuri de cancer, bolile cronice renale sau demența de tip Alzheimer (4), hipertensiune, diabet zaharat, boli pulmonare cronice obstructive sau accidente vasculare (5). Datele din literatura de specialitate indică o asociere clară între sănătatea fizică şi statusul oral, cu impact asupra abordărilor terapeutice.
$\mathrm{Cu}$ toate că studiile statistice arată date bine cunoscute privind modificările demografice, totuşi nevoile specifice legate de sănătatea fizică şi cea orală a pacienților de peste 60 de ani nu sunt încă complet înțelese. Prin urmare, o explorare amănunțită a asocierii între sănătatea generală şi statusul oral poate avea beneficii semnificative pentru a furniza servicii de sănătate mai eficiente pacienților vârstnici şi, implicit, pentru a creşte calitatea tratamentelor şi a vieții acestor pacienţi.

Articolul de față îşi propune o analiză a datelor din literatura de specialitate privind asocierea dintre statusul general şi cel oral al pacienților în vârstă şi impactul acestora asupra protezării mobile şi calității vieții lor.

\section{METODĂ}

S-a realizat un review narativ, printr-o analiză a datelor din literatură de specialitate, în acord cu scopul propus. Articolele incluse în acest studiu de literatură au fost obținute printr-o căutare în bază de date PubMed, publicate după anul 2000, folosind unul sau mai multe dintre cuvintele cheie: *oral health, *general health, *elderly, *frail, *denture, * conventional denture, *overdenture, *quality of life. Au fost, de asemenea, incluse şi unele articole identificate prin alte metode, considerate a fi relevante pentru această temă. Rezultatele au fost sortate în ordinea relevanței privind următoarele aspecte legate de persoanele în vârstă: clasificarea lor, statusul general, statusul oral, corelarea vârstei cu statusul general şi oral, modalităţi de protezare mobilă şi calitatea vieții.

\section{REZULTATE ŞI DISCUŢII}

\section{Clasificarea pacienţilor în vârstă}

Bătrânețea nu este o etapă biologică definită, deoarece vârsta cronologică, denumită ,vârstă înain- 
tată“, variază din punct de vedere cultural şi istoric (6). În general, populația în vârstă este definită în literatura de specialitate ca fiind indivizii cu vârsta de peste 60-65 de ani (7). În țările dezvoltate, cei mai mulți oameni din grupul 60-75 ani sunt încă într-o stare fizică bună, activi şi capabili să se îngrijească singuri (8). După vârsta de 75 ani, ei devin din ce în ce mai fragili, urmând o perioadă marcată de multiple dizabilități, având un profil variabil, de la cei cu stare bună de sănătate şi activi până la cei care trebuie să facă față unei multitudini de boli cronice (9). Unii gerontologi au recunoscut diversitatea vârstei înaintate prin definirea subgrupurilor de bătrâni: tineri (60-69), de vârstă mijlocie (70-79) şi longevivi $(80+)$. Definirea acestor subgrupuri în populația de peste 60 de ani permite o reprezentare mai precisă a schimbărilor semnificative ale vieții. Unii autori (Higgs şi Gilleard) au adăugat încă o subgrupă, „vârsta a patra“, pe care o descriu drept „o arenă a îmbătrânirii inactive, nesănătoase, neproductive şi, în cele din urmă, fără succes“ (10). Se consideră că există patru dimensiuni ale vârstei înaintate: cronologică, biologică, psihologică şi socială (11). Unii autori adaugă o a cincea dimensiune: dezvoltarea (12). Vârsta cronologică poate diferi considerabil de vârsta funcțională a unei persoane, semnele distinctive apar în toate cele cinci sensuri, la momente şi în grade diferite pentru persoane ce aparțin aceleiaşi categorii de vârstă.

\section{Patologia generală a pacientului vârstnic}

Bolile cronice, întâlnite frecvent drept comorbidități la pacienții vârstnici, contribuie la creşterea dizabilitătii funcționale, scad calitatea vieții şi cresc costurile îngrijirii de lungă durată şi a serviciilor de sănătate în general (13). Având în vedere faptul că mulți vârstnici prezintă mai mult de o afecțiune medicală şi simptome cauzate de numeroase boli, literatura de specialitate a adoptat termenul de „sindrom geriatric", care reflectă ideea de afectare sistemică, având caracter multifactorial şi cu un prognostic mai rezervat. În ultimul timp se vorbeşte despre afectarea sănătății orale ca un nou sindrom geriatric, ilustrat prin faptul că plurimorbiditatea şi multitudinea medicamentelor administrate unui vârstnic pot fi asociate cu sindromul de ,gură uscată“ (prin xerostomie şi hiposialie), sau cel de ,gură arsă“, asociate cu afectări generale frecvente precum fragilitate, dizabilitate, deteriorare cognitivă etc. (14).

\section{Patologia orală a pacientului vârstnic}

În rândul persoanelor în vârstă, la nivel oral, sunt frecvente probleme de sănătate orală cum ar fi: boala carioasă, parodontală, edentații, reducerea fluxului salivar (xerostomie), afecțiuni maligne. Acestea, la rândul lor, pot fi influențate sub aspect evolutiv de statutul socio-economic, de prezența unor boli sistemice asociate sau de numărul de vizite necesare la medicul stomatolog (15).

Boala parodontală este mai frecventă la vârstnici şi este asociată cu probabilitatea crescută de apariție a edentației (16). Incidența edentației totale a fost estimată ca fiind între 7\% şi 69\% la nivel internațional, cu variaţii în funcție de țară şi vârstă, fiind favorizată de o multitudine de factori generali şi locali $(17,18)$. Factori de natură biologică, legați de apariția unor patologii generale (diabet, artrită reumatoidă, hipertensiune şi boală arterială coronară), sunt corelați cu prezența edentației totale, probabilitatea de a avea placă aterosclerotică pe artera carotidă fiind de 2,32 ori mai mare (19). Datele privind asocierea osteoporozei cu boala parodontală au fost oarecum neconcludente, unele studii au arătat o uşoară asociere între osteoporoză şi resorbția osului mandibular.

Edentația este corelată şi cu unii factori legați de pacient, cum ar fi obiceiuri vicioase (fumat, consum excesiv de alcool) şi carii dentare netratate în antecedente. Pe de altă parte, edentația totală a fost asociată unor consecințe sistemice (20): dificultăți de nutriție şi de masticație, care duc la o alimentație carențială (mai ales în fructe şi legume), cu un deficit alimentar de caroteni, folați, fibre şi vitamină C (21), asociate unui risc crescut de obezitate şi boli cardiovasculare (22); inflamație cronică a mucoasei gastrice, cu o frecvență crescută a ulcerului duodenal şi gastric şi un risc crescut de cancer gastric şi intestinal (23), risc crescut de diabet (24), de hipertensiune şi accidente vasculare (25), de boală cronică renală (26), apnee (27).

\section{Corelaţii între statusul general şi cel oral la vârstnici}

Conexiuni între statusul general şi cel oral au fost dovedite în numeroase rânduri în literatura de specialitate, acestea fiind reflectate prin termenul de "oral-systemic link". S-a demonstrat faptul că inflamații cronice, fie şi de intensitate redusă (cum 
ar fi gingivitele sau parodontitele), pot contribui la boli sistemice secundare, sistemul imunitar fiind deseori deficitar. Parodontita marginală, boală inflamatorie asociată unei bacteriemii locale, poate fi asociată unei reacții inflamatorii la nivel sistemic, în diferite organe. Deşi mecanismele fiziopatologice nu sunt încă pe deplin cunoscute, s-a demonstrat existența unei asocieri între parodontită şi inflamația care apare la nivel sistemic, prin apariția unor afecțiuni precum bolile cardiovasculare, diabetul, bolile respiratorii, renale, artrita reumatoidă, afecțiunile maligne (28).

Boli cardiovasculare. Drept ilustrare a asocierii între boală parodontala şi bolile cardiovasculare, sunt referiri precum prezența patogenilor Porfiromonas gingivalis, Fusobacterium nucelatum sau Agregatibacter actinomicetemcomitans, asociați bolii parodontale, în plăcile aterosclerotice de pe intima arterelor (29).

Diabet. Asocierea între diabet şi boala parodontală este considerată a fi bidirecțională, un nivel crescut al glicemiei favorizează dezvoltarea germenilor orali, iar boala parodontală asociată unei inflamații sistemice (evidențiată prin creşterea nivelurilor proteinei $\mathrm{C}$ reactive, interleukinei IL-6, fibrinogenului, TNF- $\alpha$ şi interleukinei IL-1 $\beta$ ) poate contribui la exacerbarea rezistenței la insulină. Există corelații strânse între statusul general şi oral care se manifestă şi în relație cu vârsta şi statusul socio-economic şi cu impact asupra calității vieții.

\section{Tratamentele protetice la persoanele în vârstă}

O bună parte din populația vârstnica necesită tratament protetic, cele mai frecvente tratamente protetice fiind la aceşti pacienți cele mobile. Restaurările protetice mobile sunt de mai multe tipuri (protezări parțiale sau totale, convenționale sau supraproteze cu mijloace suplimentare de retenție pe dinți naturali/implanturi) adaptate nevoilor individuale ale pacienților, acceptării lor, dar şi posibilităților de acoperire a costurilor. Cel mai frecvent sunt utilizate protezele convenționale (mandibulare sau maxilare), mai ales în cazul vârstnicilor care suportă greu proceduri invazive. Totuşi, protezările convenţionale prezintă încă o serie de dezavantaje, fiind asociate în timp cu resorbție osoasă şi necesitatea de a fi înlocuite (30). Alte consecințe, cum sunt stomatopatiile protetice, pot apărea în urma presiunilor la care este supusă mucoasa de către proteze sau din cauza reacției alergice a mucoasei orale $(31,32)$, dar şi prin prezența biofilmului microbian (33), corelat cu un flux salivar redus (34) şi un sistem imunitar deficitar. În cazul utilizării protezelor pe termen lung, la cei cu boală Parkinson sau diskinezie mandibulară pot apărea dificultăți în masticație (35). Un alt tip de restaurări protetice utilizate la persoanele în vârstă sunt supraprotezele pe dinți şi implanturi. Rezultatele studiilor care compară diferite tipuri de restaurări protetice tind să susțină unele avantaje ale implanturilor şi/sau supraprotezelor pe implanturi, însă rezultatele nu sunt pe deplin concludente. Diferențe clare au fost legate de retenția şi stabilitatea protezelor, cei cu implanturi au raportat o satisfacție crescută (3638), dar şi ca indici ai sănătății orale (39). Rezultatele privind forța şi uşurința în masticaţie sunt incerte; în timp ce unele studii arată superioritatea implanturilor (39), altele susțin că nu există diferențe semnificative între protezele convenţionale şi supraprotezele pe implanturi în ceea ce priveşte masticația, confortul, estetica, durerea, fonația şi limitarea socială. Trebuie menționat faptul că, potrivit unor studii (39), mulţi pacienți s-au declarat mulțumiți cu proteză mobilă şi nu au dorit implanturi din cauza temerii de interevenția chirurgicală.

O dată cu înaintarea în vârstă cresc numărul de dinți cu afectare prin carie sau boală parodontală şi numărul de dinți pierduți, respectiv creşte numărul de pacienți cu forme de edentație parțială sau totală cu dificultate sporită, care necesită tratamente protetice mobile convenţionale sau pe implanturi şi care necesită intervenții medicale mai ample. Odată aplicate protezele convenționale sau pe implanturi, ele trebuie urmărite în timp pentru evaluarea şi îmbunătăţirea retenției şi stabilităţii lor, a igienei orale, a funcțiilor orale şi a interrelației cu structurile orale şi statusul general.

\section{Calitatea vieţii în rândul pacienţilor vârstnici}

Asocierea între sănătatea generală şi cea orală nu are numai o valoare obiectivă, bazată pe argumente ştiințifice, ci şi una subiectivă - aprecierea individuală. Pacienții cu o stare generală de sănătate satisfăcătoare au avut o calitate a vieții asociată sănătății orale mai bune (40). Caracteristicile socio-demografice ale pacientului - cum sunt nivelul educaţional sau cel socio-economic - pot influența semnificativ evaluarea stării personale de sănătate orală şi calitatea vieții asociată acesteia (41). 
În ceea ce priveşte sănătatea orală, calitatea vieții asociată acesteia este influențată de prezența sau absența edentaţiei şi protezării (parțiale/totale). În general, pacienții edentați care au nevoie de protezare (pe implanturi sau convențională) au o calitate a vieții mai scăzută comparativ cu cei care îşi păstrează dinții naturali şi nu necesită protezare $(40,42)$. Statusul dentar este considerat unul dintre cei mai puternici predictori ai calității vieții asociate sănătăţii orale (43). Pierderea unui anumit număr de dinți contribuie la scăderea calității vieții, posibil prin afectarea masticației, a imaginii de sine (44) şi a interacțiunii sociale (45). În rândul vârstnicilor protezați, calitatea vieții raportată la sănătatea orală a fost semnificativ asociată cu numărul de dinți naturali restanți (46), cu ulcerațiile orale şi boala carioasă (47).

Multe studii arată că supraprotezele pe implanturi sunt asociate unei calităţi mai bune a vieții pacientului (48), dar încă nu este un tratament accesibil tuturor categoriilor de pacienți, în special din cauza costurilor mai ridicate şi temerii de intervenția chirugicală de inserare a implanturilor. Într-un studiu comparativ între pacienți în vârstă cu proteză convențională versus supraprotezare pe implanturi, la 6 luni după protezare, pacienții din grupul cu proteză convențională au raportat o îmbunătățire în raport cu durerea şi disconfortul emoțional, în timp ce pacienții din grupul cu supraprotezare pe implanturi au raportat îmbunătățiri în raport cu limitarea funcțională, durere, dizabilitate fizică şi emoțională (48). Alte studii indică faptul că protezele mobile pe implanturi prezintă o serie de limitări, cum ar fi dificultăți la masticație şi disconfort general (49). Xerostomia ar putea influența în mare măsură calitatea vieții pacienților vârstnici protezați, indiferent de tipul de protezare (42).

Satisfacția privind protezarea mobilă a fost asociată cu confort, abilitatea de a utiliza proteza în masticație, aspect estetic plăcut şi stabilitatea protezelor (50), iar cei protezați de mai mulți ani tind să raporteze că sunt mai satisfăcuți, probabil datorită fenomenului de acomodare (51). Ca factori implicați în creşterea satisfacției în protezare se numără: satisfacția cu restaurarea (52); percepția soluționării edentației (53) a ulcerațiilor orale (54) şi a xerostomiei (55).
Se poate concluziona că fiecare tip de protezare prezintă avantaje şi dezavantaje, iar factorii legați de caracteristicile pacientului (vârstă, stare de sănătate, aşteptări, experienţă anterioară cu proteze etc.) pot influența atitudinea faţă de protezare şi, implicit, percepția calităţii vieții asociată protezării.

\section{CONCLUZII}

Având în vedere creşterea vârstei medii de viață şi frecvența crescută a bolilor cronice în rândul vârstnicilor, o perspectivă sistemică este absolut necesară în abordarea tratamentului prin protezare. Patologia pacientului în vârstă se accentuează o dată cu înaintarea în vârstă, crescând numărul de afecțiuni generale şi orale, numărul de medicamente şi de intervenții medicale necesare.

Edentația şi protezarea pacientului vârstnic au consecințe atât la nivel oral, cât şi asupra sănătății generale şi calității vieții. Calitatea tratamentelor şi adaptarea cu protezele la persoanele în vârstă, pe lângă dificultăţile legate de vârstă şi de modalitatea de protezare, sunt strâns asociate cu starea orală şi generală şi cu statusul socio-economic. Succesul unei protezări poate contribui la reducerea complicațiilor orale şi sistemice, la creşterea calității vieții, pe termen mediu şi lung, şi, în final, la o îmbătrânire mai armonioasă.

În contextul demografic actual şi al noilor tehnologii, este necesar ca serviciile medicale să se adapteze caracteristicilor şi nevoilor crescânde ale acestui segment populaţional important, prin instituirea unor instrumente de evaluare, prevenire şi a unor tratamente protetice potrivite, minimum invazive, care să îmbunătățească statusul oral şi sistemic şi respectiv calitatea vieții acestei categorii de pacienți defavorizați, în creştere numerică. Se impune formarea celor care tratează persoanele în vârstă, care ar trebui, pe lângă cunoaşterea aspectelor medicale specifice, să dețină şi cunoştințe şi atitudini legate de factorii sociali, psihologici, comportamentali şi financiari ce privesc persoanele în vârstă.

Mențiune. Toți autorii au avut o contribuție egală cu a primului autor în realizarea articolului. 


\section{BIBLIOGRAFIE}

1. WHO. Ageing and health. 2015. Disponibil la: https://ec. europa.eu/eurostat/statisticsexplained/index. php?title=Population_structure_and_ageing.

2. Eurostat. Population structure and ageing. Disponibil la: https://ec.europa.eu/eurostat/statistics-explained/index.php/ Population_structure_and_ageing.

3. Institutul National de Statistica. Anuarul demografic al Romaniei. 2015. Disponibil la: http://www.insse.ro/cms/files/ publicatii/pliante\%20statistice/Anuarul_demografic-PROMO. pdf.

4. Akushevich I, Kravchenko J, Ukraintseva S, Arbeev K, Yashin Al. Time trends of incidence of age-associated diseases in the US elderly population: Medicare-based analysis. Age Ageing. 2013 Jul;42(4):494-500.

5. Zhao C, Wong L, Zhu Q, Yang H. Prevalence and correlates of chronic diseases in an elderly population: A communitybased survey in Haikou. PLoS One. 2018 Jun 14;13(6):e0199006.

6. „Old age”. Oxford Reference. Disponibil la: http://www. oxfordreference.com/view/10.1093/oi/authority. 20110803100248434.

7. WHO (World Health Organization). WHO definition of an older or elderly person. 2002. Disponibil la: http://www.who. int/healthinfo/survey/ageingdefnolder/en/.

8. Berk LE. Development through the lifespan. Boston : Allyn \& Bacon; 2010.

9. Torpy JM, Lynm C, Glass RM. Frailty in Older Adults. JAMA. 2006; 296(18):2280.

10. Higgs $P$, Gilleard $C$. Rethinking Old Age - Theorising the Fourth Age. Palgrave Macmillan; 2015.

11. Phillips J, Ajrouch K, Hillcoat-Nallétamby S. Key Concepts in Social Gerontology. SAGE Publications Ltd; 2010.

12. Wattis JP, Curran S. Practical Psychiatry of Old Age (5th ed). Oxford: Radcliffe Pub; 2013.

13. Capisizu A, Zamfirescu A, Aurelian SM, Dina I. Results of prevalence study regarding comorbidities for various patients. Romanian Statistical Review. 2013;5:61-74.

14. van der Putten GJ, de Baat C, De Visschere L, Schols J. Poor oral health, a potential new geriatric syndrome. Gerodontology. 2014 Feb;31 Suppl 1:17-24.

15. Gil-Montoya JA, de Mello AL, Barrios R, Gonzalez-Moles MA, Bravo M. Oral health in the elderly patient and its impact on general well-being: a nonsystematic review. Clin Interv Aging. 2015 Feb 11;10:461-7.

16. Kassebaum NJ, Bernabé E, Dahiya M, Bhandari B, Murray CJ, Marcenes W. Global burden of severe periodontitis in 1990-2010: A systematic review and meta-regression. J Dent Res. 2014 Nov;93(11):1045-53.

17. Petersen PE, Bourgeois D, Ogawa H, Estupinan-Day S, Ndiaye C. The global burden of oral diseases and risks to oral health. Bull World Health Organ. 2005 Sep;83(9):661-9.

18. Preoteasa E, lonescu E, Băncescu G, Băncescu A, Preoteasa CT. Epidemiologic aspects of the edentulous mouth (II). General and local features of the totally edentulous mouth. Bacteriol Virusol Parazitol Epidemiol. 2005 Jan-Jun;50(1-2):27-34.

19. Desvarieux M, Demmer RT, Rundek T, Boden-Albala B, Jacobs DR Jr, Papapanou PN, Sacco RL. Oral Infections and Vascular Disease Epidemiology Study (INVEST).

Relationship between periodontal disease, tooth loss, and carotid artery plaque: the Oral Infections. and Vascular Disease Epidemiology Study (INVEST). Stroke. 2003 Sep;34(9):2120-5.
20. Emami E, de Souza RF, Kabawat M, Feine JS. The impact of edentulism on oral and general health. Int J Dent. 2013;2013:498305.

21. Felton DA. Edentulism and comorbid factors. J Prosthodont. 2009 Feb;18(2):88-96.

22. Österberg T, Dey DK, Sundh V, Carlsson GE, Jansson JO, Mellström D. Edentulism associated with obesity: a study of four national surveys of 16416 Swedes aged 55\&\#x2013;84 years. Acta Odontol Scand. 2010 Nov;68(6):360-7.

23. Stolzenberg-Solomon RZ, Dodd KW, Blaser MJ, Virtamo J, Taylor PR, Albanes D. Tooth loss, pancreatic cancer, and Helicobacter pylori. Am J Clin Nutr. 2003 Jul;78(1):176-81.

24. Medina-Solís CE, Pérez-Núñez R, Maupomé G, Avila-Burgos L, Pontigo-Loyola AP, Patiño-Marín N, Villalobos-Rodelo JJ. National survey on edentulism and its geographic distribution, among Mexicans 18 years of age and older (with emphasis in WHO age groups). J Oral Rehabil. 2008 Apr;35(4):237-44.

25. Okoro CA, Balluz LS, Eke PI, Ajani UA, Strine TW, Town M, Mensah GA, Mokdad AH. Tooth loss and heart disease: Findings from the Behavioral Risk Factor Surveillance System. Am J Prev Med. 2005 Dec;29(5 Suppl 1):50-6.

26. Fisher MA, Taylor GW, Shelton BJ, Jamerson KA, Rahman M, Ojo AO, Sehgal AR. Periodontal disease and other nontraditional risk factors for CKD. Am J Kidney Dis. 2008 Jan;51(1):45-52.

27. Bucca C, Cicolin A, Brussino L, Arienti A, Graziano A, Erovigni F, Pera P, Gai V, Mutani R, Preti G, Rolla G, Carossa $\mathrm{S}$. Tooth loss and obstructive sleep apnoea. Respir Res. 2006 Jan 17;7:8.

28. Kumar PS. From focal sepsis to periodontal medicine: A century of exploring the role of the oral microbiome in systemic disease. J Physiol. 2017 Jan 15;595(2):465-476.

29. Figuero $E$, Sánchez-Beltrán $M$, Cuesta-Frechoso $S$, Tejerina JM, del Castro JA, Gutiérrez JM, Herrera D, Sanz M. Detection of periodontal bacteria in atheromatous plaque by nested polymerase chain reaction. J Periodontol. 2011 Oct;82(10):1469-77.

30. Polzer I, Schimmel M, Müller F, Biffar R. Edentulism as part of the general health problems of elderly adults. $t$ Dent $\mathrm{J}$. 2010 Jun;60(3):143-55.

31. Preoteasa E. Aspecte clinice şi terapeutice la edentaţi total cu modificări ale statusului oral. Bucuresti, Editura Universitară, 2005.

32. Iosif L, Preoteasa E. Stomatită protetică - actualizări în etiologie, diagnostic şi tratament. Bucureşti, Editura Universitară „Carol Davila“; 2013.

33. Page RC. The pathobiology of periodontal diseases may affect systemic diseases: Inversion of a paradigm. Ann Periodontol. 1998 Jul;3(1):108-20.

34. Preoteasa E, Tâncu AM, losif L, Melescanu Imre M, MurariuMăgureanu C, Preoteasa CT. Salivary changes related to systemic diseases in the edentulous patients. J Med Life. 2014 Oct-Dec;7(4):577-80.

35. Müller F, Schimmel M. Tooth loss and dental prostheses in the oldest old. European Geriatric Medicine. 2010; 1(4):239243.

36. Preoteasa E, Meleşcanu-Imre M, Preoteasa CT, Marin M, Lerner $\mathrm{H}$. Aspects of oral morphology as decision factors in mini-implant supported overdenture. Rom J Morphol Embryol. 2010;51(2):309-14.

37. Preoteasa E, Imre M, Preoteasa CT. A 3-year follow-up study of overdentures retained by mini-dental implants. Int J Oral Maxillofac Implants. 2014 Sep-Oct;29(5):1170-6. 
38. Preoteasa E, Imre M, Lerner H, Tancu AM, Preoteasa CT. Narrow Diameter and Mini Dental Implant Overdentures. In: Virdi MS (ed.). Emerging Trends in Oral Health Sciences and Dentistry. IntechOpen; 2015:241:264.

39. Assunção WG, Zardo GG, Delben JA, Barão VA. Comparing the efficacy of mandibular implant-retained overdentures and conventional dentures among elderly edentulous patients: Satisfaction and quality of life. Gerodontology. 2007 Dec;24(4):235-8.

40. de Andrade FB, Lebrão ML, Santos JL, da Cruz Teixeira DS, de Oliveira Duarte YA. Relationship between oral healthrelated quality of life, oral health, socioeconomic, and general health factors in elderly Brazilians. J Am Geriatr Soc. 2012 Sep;60(9):. 1755-60.

41. Mariño R, Schofield M, Wright $C$, Calache $H$, Minichiello V. Self-reported and clinically determined oral health status predictors for quality of life in dentate older migrant adults. Community Dent Oral Epidemiol. 2008 Feb;36(1):85-94.

42. Hahnel S, Schwarz S, Zeman F, Schäfer L, Behr M. Prevalence of xerostomia and hyposalivation and their association with quality of life in elderly patients in dependence on dental status and prosthetic rehabilitation: A pilot study. J Dent. 2014 Jun;42(6). :664-70.

43. John MT, Koepsell TD, Hujoel P, Miglioretti DL, LeResche L, Micheelis W. Demographic factors, denture status and oral health-related quality of life. Community Dent Oral Epidemiol. 2004 Apr;32(2):125-32.

44. Wöstmann B, Michel K, Brinkert B, Melchheier-Weskott A, Rehmann $\mathrm{P}$, Balkenhol M. Influence of denture improvement on the nutritional status and quality of life of geriatric patients. J Dent. 2008 Oct;36(10):816-21.

45. Knezović Zlatarić D, Celebić A, Valentić-Peruzović M, Jerolimov V, Pandurić J. A survey of treatment outcomes with removable partial dentures. J Oral Rehabil. 2003 Aug; 30(8):847-54.

46. Joaquim AM, Wyatt CC, Aleksejūnienè J, Greghi SL, Pegoraro LF, Kiyak HA. A comparison of the dental health of Brazilian and Canadian independently living elderly. Gerodontology. 2010 Dec;27(4):258-65.
47. Swoboda J, Kiyak HA, Persson RE, Persson GR, Yamaguchi DK, MacEntee MI, Wyatt CC. Predictors of oral health quality of life in older adults. Spec Care Dentist. 2006 Jul-Aug; 26(4):137-44.

48. Heydecke G, Locker D, Awad MA, Lund JP, Feine JS. Oral and general health-related quality of life with conventional and implant dentures. Community Dent Oral Epidemiol. 2003 Jun;31(3):161-8.

49. Gates WD 3rd, Cooper LF, Sanders AE, Reside GJ, De Kok IJ. The effect of implant-supported removable partial dentures on oral health quality of life. Clin Oral Implants Res. 2014 Feb;25(2):207-13.

50. Zlatarić DK, Celebić A. Factors related to patients' general satisfaction with removable partial dentures: a stepwise multiple regression analysis. Int J Prosthodont. 2008 Jan-Feb;21(1):86-8.

51. Abuzar MA, Kahwagi E, Yamakawa T. Investigating oral health-related quality of life and self-perceived satisfaction with partial dentures. J Investig Clin Dent. 2012 May;3(2):109-17.

52. Stober T, Danner D, Lehmann F, Séché AC, Rammelsberg P, Hassel AJ. Association between patient satisfaction with complete dentures and oral health-related quality of life: Two-year longitudinal assessment. Clin Oral Investig. 2012 Feb;16(1):313-8.

53. Komagamine $Y$, Kanazawa M, Kaiba Y, Sato Y, Minakuchi S, Sasaki Y. Association between self-assessment of complete dentures and oral health-related quality of life. J Oral Rehabil. 2012 Nov;39(11):847-57.

54. Suliman NM, Johannessen AC, Ali RW, Salman H, Astrøm AN. Influence of oral mucosal lesions and oral symptoms on oral health related quality of life in dermatological patients: A cross sectional study in Sudan. BMC Oral Health. $2012 \mathrm{Jul}$ 8;12:19.

55. Zaitsu T, Ueno M, Shinada K, Ohara S, Wright FA, Kawaguchi Y. Association of clinical oral health status with self-rated oral health and GOHAl in Japanese adults. Community Dent Health. 2011 Dec;28(4):297-300. 